\title{
The Comprehensive and Strict Management of Communist Party of China and the Practice of China's Good Political Ecology
}

\author{
Yufang Zhang \\ Sichuan University, Chengdu, Sichuan Province, China
}

Keywords: Governing party, Politics, Political ecology, the Chinese party.

\begin{abstract}
Political ecology reflects a country's political life of the climate and environment. They are the concentrated expression of the party, government ethics, social conduct and morals, which orientation value of political activity has a great influence and the behavior choice. When the political ecology is good, the logical administration and ecology air are fresh, while if the political ecology is bad and divided, the wind gas will be cloud. The comprehensive governing party has a strong positive correlation in good politics. At present, it must pass through serious inner-party political life continues to push forward the comprehensive governing party, to build the fresh air for Chinese politics.
\end{abstract}

\section{Political Ecology and Governance of the Party in Power}

Political ecology is a concept of diversity and connotation. In simple terms, the political ecology is the state of political life, that is, the overall state of the internal elements of the political system and the ecological linkage between the political system and other social systems. In China's political context, political ecology is equivalent to political environment, official ecology and political action (the comprehensive reflection of the political atmosphere of the Party style). Value orientation and behavior practice of political actors are the keys to the formation, development and evolution of political ecology. The interactive practice of the actors directly constructs the political ecology, which directly affects the value orientation and political behavior of these political actors. At the same time, good political ecology is conducive to the balance and circulation of political relations, so does the establishment and stability of political order, to enhance the certainty and acceptability of political behavior patterns, and to support the formation of political evaluation standards and internal values of political consensus. And the poor political ecology, due to the internal mechanism and the occurrence mechanism are distorted, continue to produce "negative" energy and "anti" effect, to stimulate the internal decay of political systems, which may lead to loss of political value and order, deterioration of political relations, distortions of political behavior, until the collapse of political system ultimately. Therefore, construction of an excellent political ecology is the key to keep stable and orderly equilibrium of any political system.

In modern political life, political parties are the most active and influential political (organizational) subject. As a bridge between government and society, political parties aim to gain consolidate political power, participate in the regime, which have the functions of interest expression, benefit integration, political recruitment and political socialization. Due to all these, political parties are at the core and key position in political system, with own subsystem characteristics, has particularly close relationship with the political ecology. Political ecology, as a political, effects people's mind and the rise and fall of political parties.

Among them, the ruling party, at the center of political power system, its development has more obvious interaction with political ecology. In this respect, the experience in some other countries of the world is worthy of study and reference, such as the CPSU, the Indian Congress Party, the Mexican Revolutionary Institution Party, due to ruling parties are not in leading position, which lead to 
political deterioration, then lose the ruling position ultimately. Although reasons behind the death of the Soviet Communist Party are complicated and diverse, the root cause is that they cannot keep up with the times to strengthen the party's construction, which leads to the party is not strict, government is not honest and finally abandoned by the people. The fundamental reason of India's Congress Party and Mexican Revolutionary Party lost its long-standing status is that lacking effective supervision to long-term independence, which lost the people ultimately and step down sadly. The Singapore People's Action Party is just on the contrary, in the long process of ruling, through the rule of law, high salaries and other ways, build a clean political system and cohesion the people, not only build a good political ecology, but also maintain its own stable ruling for more than 50 years.

In short, "political ecology is good, people on the cis, righteousness on the foot; political ecology is not good, people will be lax, shortcomings arise." Good political ecology of is not only a necessary condition for the survival and development of ruling party itself, but also plays a decisive role in the formation and evolution of the overall political ecology, and thus has a decisive influence on the construction of the fine political ecology, as a result, has more important and direct responsibility to the construction of the fine political ecology. In this sense, the key to the construction of a good political ecology is to strengthen the ruling party governance, and then promote the country's generation of good political ecology of through purification, reconstruction and optimization of political ecology.

\section{The Construction of A Good Political Ecology is the Inherent Appeal of Communist Party if China Aimed to Establish A Comprehensive and Rigid Strategy}

In contemporary China, the political ecology is not only an important symbol to measure whether the state politics is clear or the society is of harmony and stability, but also a key content of the party's ruling and rejuvenating the country.

The Communist Party if China is the vanguard of the Chinese working class and the vanguard of the Chinese people and the Chinese nation. The core and only ruling position of Communist Party if China is inevitable base on development of modern China. It is the result of the people's support and choice, the realistic needs of the great rejuvenation of the Chinese nation under the new historical conditions. Therefore, the political niche of the Communist Party if China determines that there is a clear positive correlation between the Party's own governance and the political ecology. On one hand, the Party's long-term ruling position needs the support of good political ecology, on the other hand, the effect of ruling the party directly determines the political ecology. Therefore, the good political ecology has become the basic content and inevitable demands of Communist Party if China to rule the party strictly and resolutely.

During the past 30 years of reform and opening, the profound changes in world situation, national conditions and the party's situation have made the Party facing governance, reform and opening, market economy and external environment these four challenges at the same time, which still exists spiritual slack, lack of capacity, away from the people and negative corruption these "four dangers." In this regard, Communist Party if China put forward the strategy of "four comprehensive" and "comprehensive strict rule of the party" to strengthen the party building in 2014. However, "to strengthen the party building, do all aspects of work" is on the condition of creating a good political environment, that is, to have a good political ecology. Political ecology is dirty, political environment is bad; political ecology is good, political environment is fine. Political ecology is just like natural ecology, which is easy to be polluted, once problems happened, a great price need to be paid to restore. "In recent years, the experience of building a clean government has shown that the Party building is very difficult and the Party's problems is difficult to cure in lacking a good political ecology. From a number of typical cases handled since the 18th National Congress of the Communist Party of China, some local bribery case, corruption case, official positon sales occurred in some place are related to poor local political ecology. Although the new style of building a clean government and anti-corruption struggle has obviously improved the political ecology, but all kinds of unspoken rules, large and small network of relationships, reversing "bad money to drive out good money", incorrect wind of using people, The existence of such problems contradict the comrades within the party and 
even the whole country's good political ecology, such as the "lazy" of formalism, "cadres" of party members, "luxury" of extravagance, illegal "corruption" and other symptoms.

Therefore, to optimize and rebuild good political ecology to ensure honest and upright Party and country political life is an important issue that the Communist Party if China must explore and solve deeply, which is an important content and an inner demand of ruling the Party strictly in an all-round way, also the of political choice of the Party to unite the people to achieve two a hundred years' fighting goal.

\section{The Formation of Good Political Ecology Must Be Based on A Comprehensive and Serious Political Life within the Party}

Facts have proved that China's future relies on the Party. Upholding the party's leadership is the basis and prerequisite for doing all the work, so does the fundamental guarantee for the continuous success of Chinese characteristics socialism. In socialist China, the Party is the core of the national and social undertakings, which is in the overall and coordination status. The Party thrives, enterprise thrives; the Party is strong, the country is strong. In 1992, Xiaoping Deng pointed out in the South Talks clearly that "if the socialist countries have problem, the problems are from the Communist Party." Comrade Xi Jinping also pointed out that "Ruling the Communist Party if China well is the premise to improve the whole country."

Once the national political ecology has a problem, the Communist Party need to be the first object to find causes, therefore great efforts need to be paid to rule the party and government. The current political and ecological deterioration is the result of poor ruling of the Party. Therefore, a comprehensive and strict ruling to the Party is the key to build a good political ecology of "clean government, clean government, upright politics" to fully clean the party's political ecology, guarding for the sustainable development of political ecology, and then lead the whole country's political ecology reconstruction and optimization.

"Where does the good political ecology come from? First of all, from the serious political life within the party." This is a key point of strict control of the party, but also the current construction of a good political ecology of the key starting point and basically follow. The Party must keep the party from the political life of the party, and the party must be strict from the political life of the party. "Facts show that the political life within the party serious, party style wind will not have any big problem; a local political and ecological problems, first of all, the political life of the party is a problem.

Under the new situation, the overall political life of the party is good, but there are some such as "ideals and beliefs are not firm, loyalty to the party, discipline relaxation, from the masses, arbitrary, fraud, indiscriminate, individualism, decentralism, Liberalism, good doctrine, sectarianism, doctrine, worship of the existence of different degrees, formalism, bureaucracy, hedonism and extravagant wind problems prominent, cronyism, run officials to officials, buy and sell officials, canvassing bribes election phenomenon repeated, Abuse of power, corruption and bribery, corrupt corruption, illegal and other phenomena spread and spread, especially in the senior cadres of a very small number of political ambitions to expand, the right to fool, engage in yin and yang, party business, gangs, gangs, And other political conspiracy activities "and other prominent issues, seriously undermine the party's political ecology, seriously affecting the party and the cause of the development of the people.

How can the political ecology of the party be purified through the "strict" and "tube" of political life within the party? "On the new situation under the party's political life of a number of guidelines" to make a clear provision for this.

First, to strengthen the party's political culture. The inner political culture of the party is a political environment for the political environment of political parties. To build a good political ecology, to promote a comprehensive and strict governance of the party, we must first continue to strengthen the party's political culture, adhere to the ideological party. "The ideal and belief is the spirit of the Communist Party 'calcium"' "There is no ideal faith, ideals and believes are not firm, the spirit will be 'calcium deficiency', will be 'rickets'." Firm belief is to build a good political ecology key. At present, the primary task of inner-party political life is through the continuous study, firm ideals and beliefs 
and cultural self-confidence, firm communist lofty ideals and the common ideals of socialism with Chinese characteristics. At the same time build up the ideological and defensive line of anti-corruption, to maintain a clean and honest political character, adhere to the spirit of the Communists, and guide party members and cadres' correct political ideology, strengthen political identity.

Second, to establish a normal inner-party political relations. It is an important principle and requirement to build a good political ecology within the party, based on the same way and the unity of the party members' rights and equality. It is an important foundation for the active and healthy political life of the party to uphold and perfect the democratic system within the party and improve the quality of inner-party democracy. And respect for the status of party members to protect the democratic rights of party members, the implementation of party members the right to know, the right to participate, the right to vote, the right to monitor the establishment of legitimate political relations within the main manifestation.

Third, to strengthen and improve the party system construction. Purify the party's political ecology, discipline, rules and system are three important factors and links. "The party is to control the party, strict governance of the party, rely on what the tube, what is the rule is to be strict discipline." The first is strict political discipline and political rules, which is serious political life within the party, building a good political ecology of the important content The Second, we must strictly discipline, by seriously punishing violations of discipline, party discipline and rules can become a rigid political environment to build a rigid constraint. Again, to promote the standardization of party organization and life, to purify the political ecology to create a good "climate" environment. Party organization and life is an important content and carrier of political life within the party. Democratic centralism is the fundamental organizational principle of the party, is the party's political life to carry out an important system of protection, but also an important guarantee for the purification of political ecology within the party. To carry out criticism and self - criticism is an important means to strengthen and standardize the political life within the party. Finally, to strengthen the power of the constraints and supervision mechanism is to strengthen and regulate the political life within the party an important measure. Make the power transparent is the key to strengthen the supervision of the government and the leaders' right, especially leaders'.

Fourth, to insist on correct selection of people oriented. To build a good political ecology, to rely on outstanding cadres to drive and promote a comprehensive strict rule of the party, the key is to build a political firm, capable, fine style, strong and effective high-quality backbone of the ruling team, strengthen the leading role of leading cadres. Adhere to the correct selection of people-oriented, is a serious party within the political life of the organization to ensure that the political environment is the benchmark. "If the employment orientation is not correct, the harm is the source of political ecology. To create a good political ecology, we should adhere to the correct use of people as a radical policy, and further highlight the selection and employment of a good atmosphere." In the ruling backbone of the selection and appointment must be strict Standards, sound system, improve the policy, and standardize the procedures, so that the elected cadres to rest assured that the masses satisfied with the cadres convinced, from the source to ensure that "beautiful" political ecology from pollution.

Fifth, strengthen the party's style of construction, severely punish corruption. "A place, a unit of political ecology is good, there are two intuitive rulers: a look at party members and cadres style is good, see if there is no corruption." Historical experience shows that "if not resolutely correct bad atmosphere, let it develop, which will be like an invisible wall to our party and the people separated, our party will lose foundation, lose blood, lose power. "Bad atmosphere is a hotbed of corruption which is an important manifestation of political deterioration. Therefore, to build a good political ecology, the need for style construction as the starting point to maintain the corruption of the heavy pressure situation, in accordance with the requirements of General Secretary Xi Jinping "determined to have rotten, there must be Su, continue to eradicate the spread of corruption Soil ", improve the anti-corruption system, in order to purify the party style wind and wind, to create a good political environment. 
In short, for the Communist Party if China, the construction of an excellent political ecology is necessary to win the hearts of the people, win the world, consolidate the ruling position and realize the historical mission, and the political ecology depends on the values and behavioral practice leading by the Communist Party if China. At present, only through the continuous and comprehensive strict rule of the party, especially from the political culture, political relations, political system, political subject and other aspects to clean political life within the party, in order to achieve the political goal.

\section{References}

[1]Yunshan Liu. Strive to create a good political ecology [J]. Learning Times, 2015 (6).

[2] Central Literature Research Office. General Secretary Xi Jinping important speech articles selected [M]. Beijing: Central Literature Publishing House, 2016: 157.

[3]Deng Xiaoping's anthology: Volume 3 [M]. Beijing: People's Publishing House, 1993: 380.

[4]Central Literature Research Office. General Secretary Xi Jinping important speech articles selected [M]. Beijing: Central Literature Publishing House, 2016: 155-156.

[5]Yunshan Liu, strive to create a good political ecology [J]. Learning Times, 2015 (6).

[6]Yunshan Liu, strive to create a good political ecology [J]. Learning Times, 2015 (6).

[7]Several Criteria for the Political Life of the Party in the New Situation (Xinhua News Agency, November 27, 2016, the Central Committee of the Eighteenth Central Committee of the Communist Party of China on October 27, 2016).

[8]Communist Party if China Press, People's publishing House, 2016: 106. Beijing: Learning Press, People's publishing House, 2016: 106.

[9]Selected literature since the 18th major [M]. Volume. Beijing: Central Literature Publishing House, 2014: 764.

[10]Yunshan Liu. Create a good political ecology [J]. Learning Times, 2015 (6).

[11]Yunshan Liu. Strive to create a good political ecology [J]. Learning Times, 2015 (6).

[12]Xi Jinping' comments on governance country governance [M]. Beijing: foreign language publishing house, 2014: 387.

[13]Xi Jinping on the building of clean government and anti-corruption struggle excerpts [M]. Beijing: Central Literature Publishing House, 2015: 94. The Central Committee of the Communist Party of China (CPC) Central Committee of the Communist Party of China (CPC). 